\title{
PENERAPAN SISTEM MONITORING HEALTHY SMART HOME DENGAN EARLY WARNING SYSTEM
}

\author{
Angga Pratama Priga Putra, Suryo Adi Wibowo, Yosep Agus Pranoto \\ Program Studi Teknik Informatika S1, Fakultas Teknologi Industri \\ Institut Teknologi Nasional Malang, Jalan Raya Karanglo km 2 Malang, Indonesia \\ 1618090@scholar.itn.ac.id
}

\begin{abstract}
ABSTRAK
Kesehatan tubuh setiap anggota keluarga, sangat dipengaruhi oleh kesehatan tempat tinggal itu sendiri. Helathy smart home menjadi salah satu sarana untuk mencapai derajat kesehatan yang optimum. Untuk memperoleh rumah yang sehat ditentukan oleh beberapa faktor seperti tersedianya pencahayaan dan kelembaban yang cukup, serta suhu yang sejuk. Selain itu sistem monitoring dan peringatan dini diperlukan guna mendukung penghuninya agar dapat hidup dengan nyaman dan aman.

Pada umumnya sistem monitoring belum dapat dilakukan dengan jarak jauh, sehingga dibuat suatu simulasi miniatur Helathy smart home dengan early warning system. Dimana sensor DHT11, sensor ldr yg berfungsi untuk monitoring suhu, kelembaban dan intensitas cahaya pada ruangan, serta sensor MQ-6 digunakan untuk mendeteksi gas pada ruangan yg terdapat kipas untuk mengeluarakan gas yang dapat diatur kecepatan putarnya berdasarkan kadar gas, water level sensor untuk mendeteksi adanya air, flame sensor untuk mendeteksi adanya api yang terhubung dengan early warning system berupa notifikasi melalui email.

Alat dapat bekerja dengan cukup baik, hal ini ditunjukkan dengan semua komponen berjalan sesuai dengan yang di harapkan, mampu mendeteksi dan memonitoring lalu menampilkanya dalam bentuk website. Sensor dht11 persentase error dari sensor tersebut sebesar 4,34\% untuk suhu dan 36,72\% untuk kelembaban. Sensor ldr persentase error dari sensor tersebut sebesar 13,74\%. flame sensor mampu mendeteksi api dengan mengguanakan lilin dengan jarak maksimal $75 \mathrm{~cm}$. water level sensor saat tidak ada air nilai sensor $<=100$, ketinggian air rendah nilai sensor $>100 \&<=260$, ketinggian air sedang nilai sensor $>260 \&<=325$, ketinggian air tinggi nilai sensor $>325$. Serta Website dapat berjalan dengan baik pada browser Mozilla firefox (77.01), Microsoft edge (44.18362.449.0), dan google chrome (83.0.4103 .97).
\end{abstract}

Kata Kunci : early warning system, Internet of things, Arduino uno

\section{PENDAHULUAN}

Pada umumnya monitoring dan kontroling selama ini masih dilakukan menggunakan PLC dan belum dapat dikontrol dengan jarak jauh (Prasaja, a. $P$, 2013), pekerjaan monitoring dan kontroling tersebut harus dengan pengawasan manual dan juga membutuhkan waktu yang sangat lama disaat harus mengontrol dan monitor beberapa bangunan. Dengan sistem seperti itu maka sangat kurang optimal untuk memonitoring dan kontroling bangunan pada zaman yang kemajuan teknologi sudah sangat mutakhir.

sehingga dibuat suatu simulasi miniatur Healthy smart home. Dimana sensor DHT11 untuk memonitoring suhu dan kelembaban, sensor ldr yg berfungsi untuk monitoring intensitas cahaya pada ruangan, sensor MQ-6 digunakan untuk mendeteksi gas pada ruangan yg terdapat kipas mengarah ke luar ruangan untuk mengeluarakan gas yang dapat diatur kecepatan putarnya berdasarkan kadar gas, water level sensor untuk mendeteksi adanya air, flame sensor untuk mendeteksi adanya api yang terhubung dengan early warning system berupa notifikasi melalui email.

\section{TINJAUAN PUSTAKA}

\subsection{Penelitian Terdahulu}

Berdasarkan penelitian yang dilakukan oleh Joseph Dedy Irawan, Sonny Prasetio, Suryo Adi Wibowo (2015), dilakukan penelitian tentang Early warning system for building automation system. dalam penelitian ini peralatan yang digunakan untuk memantau dan mengeksekusi perintah adalah Programmable Logic Control (PLC), dengan menggunakan PLC sebagai perangkat kontrol dapat dibuat sistem peringatan dini, di mana sistem akan mendeteksi beberapa sensor yang akan menginformasikan pemilik melalui SMS jika ada kasus gangguan di rumah.[1]

Penilitian pertama dilakukan oleh Akh. Farid (2017), tentang Rancang Bangun Sistem Monitoring Dan Kontroling Pada Smart Building Dengan Penerapan Iot (Internet Of Things) menggunakan modul wifi ESP8266 untuk send dan request data pada web server dari jarak jauh, serta menggunakan konsep IoT (Internet of Things), dan Aplikasi sistem monitoring dan kontroling pada smart building dapat berjalan di operating system android.[2]

Penilitian ke-dua dilakukan Saifullana (2018) tentang sistem pendeteksi kebakaran rumah terintegrasi smartphone dan aplikasi online Dari hasil uji coba yang dilakukan, sistem ini berhasil 
mendeteksi adanya api, asap, dan suhu. Pompa air sebagai media pemadam api mampu bekerja dengan baik saat sensor mendeteksi adanya kebakaran dan buzzer berbunyi untuk memberikan peringatan terhadap pemilik rumah.[3]

Penilitian ke-tiga dilakukan Wahyu Indianto (2017) tentang perancangan sistem prototipe pendeteksi banjir peringatan dini menggunakan arduino dan php. telah dibangun sebuah sistem prototipe pendeteksi banjir peringatan dini menggunakan Arduino dan PHP yang memudahkan pengguna untuk mengetahui keadaan luapan air di parit pengguna[4]

Penilitian ke-empat dilakukan Widyanto (2014) tentang alat deteksi kebocoran tabung gas elpiji berbasis mikrokontroler. Alat deteksi kebocoran gas LPG mampu mendeteksi adanya kebocoran gas LPG. Outputnya adalah sebuah buzzer akan dibunyikan jika terjadi kebocoran gas LPG.[5]

Penilitian ke-lima dilakukan Zulhipni (2016) tentang perancangan monitoring suhu ruangan menggunakan arduino berbasis android.Sistem ini dapat dimonitoring kapan AC diperlukan dan kapan harus dimatikan, sedangkan dari segi kemanan dapat diketahui kapan ruangan dalam kondisi aman dan kapan berbahaya, Modul LCD menampilkan hasil dari monitoring suhu yang dihasilkan oleh sensor suhu LM35. [6]

\subsection{Dasar Teori}

\subsubsection{Internet Of Things}

Internet of Things (loT) adalah sebuah istilah yang muncul dengan pengertian sebuah akses perangkat elektronik melalui media internet. Akses perangkat tersebut terjadi akibat hubungan manusia dengan perangkat atau perangkat dengan perangkat dengan memanfaatkan jaringan internet. Akses perangkat tersebut terjadi karena keinginan untuk berbagi data, berbagi akses, dan juga mempertimbangkan keamanan dalam aksesnya.

Internet of Things (loT) dimanfaatkan sebagai media pengembangan kecerdasan akses perangkat di dunia industri, di rumah tangga, dan beberapa sektor yang sangat luas dan beragam (contoh : sektor lingkungan, sektor rumah sakit, sektor energi, sektor umum, sektor keamanan, dan sektor transportasi). Internet of Things (IoT) dapat dikembangkan dengan media perangkat elektronika yang umum seperti arduino untuk keperluan yang spesifik (khusus). loT juga dapat dikembangkan aplikasi terpadu dengan sistem operasi android.[7]

\subsubsection{Early Warning System}

Salah satu implementasi data mining yang paling sukses adalah monitoring. Metode semacam ini memiliki aplikasi yang sangat luas, seperti pendeteksi dini wabah penyakit, penipuan perbankan, serta early warning system untuk pendeteksi perilaku mencurigakan pada rekaman video.Tujuan dari semua masalah tersebut adalah untuk memproses data secara dinamis, secepat mungkin sebagai tindakan awal.

Karakteristik nya adalah streaming data secara berkala, sangat berbeda dengan masalah statistic klasik yang dapat di analisa dan analisa ulang di dalam laboratorium, yang berarti analisis harus segera dilakukan sebelum data hilang dan sistem memeperoleh data potensial terbarunya. Selin itu masalah dari data streaming yaitu adanya sejumlah data dalam set yang besar yang terus update secara berkelanjutan. Karakteristik ketiga adalah tujuannya adalah pendeteksi dini, sehingga dibutuhkan intervensi yang tepat waktu. Tiga fitur dari data ini sifatnya yang dinamis dan berkelanjutan, ukuran set data, dan tujuan pemberian peringatan dini.[8]

\subsubsection{Arduino Uno}

Menurut Abdul Kadir, Arduino Uno adalah salah satu produk berlabel arduino yang sebenarnya adalah suatu papan elektronik yang mengandung mikrokontroler ATMega328 (sebuah keping yang secara fungsional bertindak seperti sebuah komputer). Piranti ini dapat dimanfaatkan untuk mewujudkan rangkaian elektronik dari yang sederhana hingga yang kompleks. Pengendalian LED hingga pengontrolan robot dapat diimplementasikan dengan menggunakan papan berukuran relatif kecil ini. Bahkan dengan penambahan komponen tertentu, piranti ini bisa dipakai untuk pemantauan kondisi pasien di rumah sakit dan pengendalian alat-alat di rumah.[9]

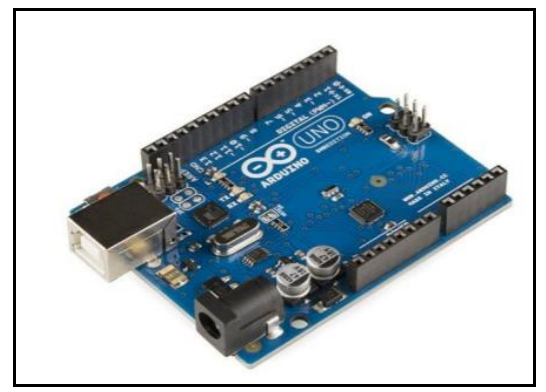

Gambar 1 Arduino uno

\section{METODE PENELITIAN}

\subsection{Analisis Kebutuhan}

Analisis kebutuhan penerapan sistem monitor ing pada Helathy smart home dengan early warning system, meliputi beberapa jenis yaitu sebagai berikut :

1. Kebutuhan Fungsional : monitoring data real time dan early warning system berbasis web

2. Kebutuhan Development :

a. Hardware :Arduino uno, ESP 8266, DHT11, MQ-6, Flame sensor, Ldr sensor, Water Level Sensor, Fan, Buzzer, Water Atomizer,

b. Software : Arduino IDE, XAMPP, Sublime text 3, web browser 


\subsection{Blok Diagram Sistem Monitoring}

Blok diagram adalah diagram dari sebuah sistem, di mana DHT11, MQ-6, Ldr sensor, water level sensor, flame sensor sebagai alat masukan untuk mendeteksi, Arduino Uno Sebagai alat pemrosesan, kipas/fan, buzzer, humidifier/water atomizer sebagai output. Serta ESP8266 sebagai penghubung pada proses pengiriman data. Proses kerja pada alat ini di tunjukkan pada Gambar 2

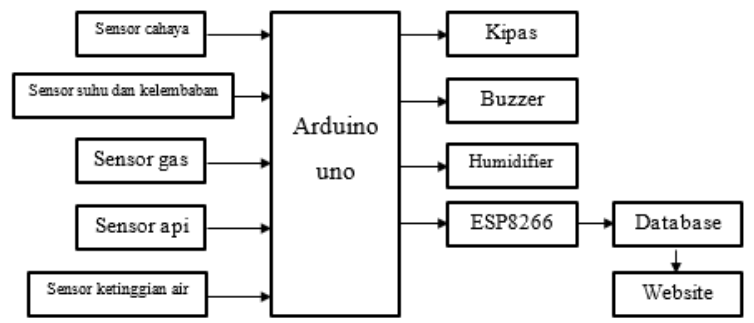

Gambar 2 Blok diagram sistem monitoring Helathy smart home

\subsection{Flowchart Sistem}

Flowchart sistem ini menjelaskan proses berjalananya aplikasi seperti ditunjukkan pada Gambar 3.
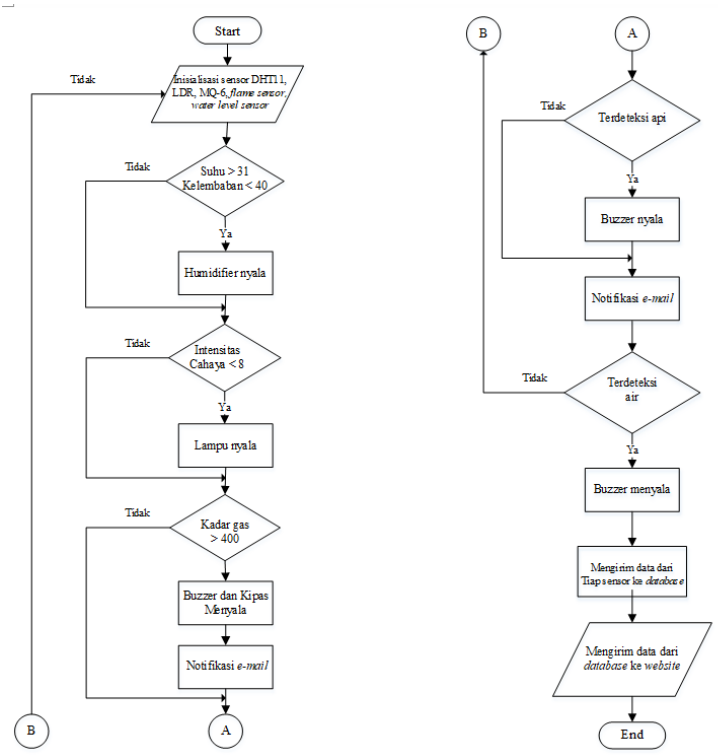

Gambar 3 Flowchart Sistem

Berdasarkan flowchart pada Gambar 3, sistem Dimuali dari inisiasi sensor dht11, sensor ldr, sensor mq-6, flame sensor dan water level sensor, kemudian jika suhu > 31 dan kelembaban < 40 maka humidifier akan menyala. jika intensitas cahaya $<8$ maka lampu akan menyala. jika kadar gas $>400$ maka kipas dan buzzer akan menyala dan mengirimkan notifikasi email. jika terdeteksi api maka buzzer akan menyala dan mengirimkan notifikasi email. jika terdeteksi air maka buzzer akan menyala. Kemudian data dari setiap sensor di kirim ke database dan data akan di tampilkan di website.

\section{IMPLEMENTASI DAN PENGUJIAN \\ 4.1 Implementasi}

Pada proses perancangan hardware, digunakan kabel jumper untuk menghubungkan antara pin yang terdapat pada mikrokontroler dengan sensor dht11, sensor mq-6, sensor ldr, flame sensor, water level sensor, fan, buzzer, water atomizer dan modul wifi.

\subsubsection{Hasil Implementasi Hardware}

Berdasarkan hasil analisis dan perancangan pada Bab III. Diimplementasikan penerapan sistem monitoring Helathy smart home dengan early warning system sebagai berikut :

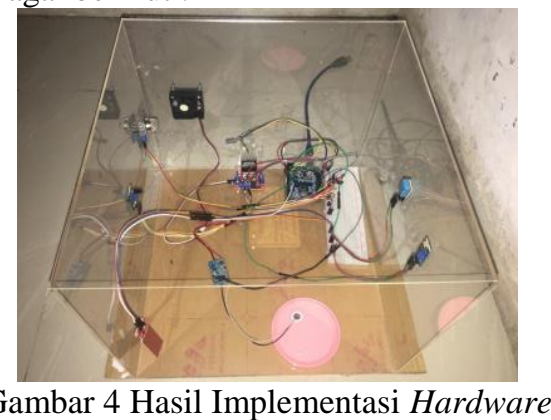

Model desain sistem monitoring Healthy smart home dengan early warning system yang dibuat sesuai dengan perancangan hardware. Pada Gambar 4.1 menunjukkan model desain hardware yang terdiri dari beberapa komponen dengan fungsi dan tugas masing - masing. Pengujian ini dilakukan untuk mengetahui pembacaan sensor dht 11, sensor mq-6, sensor ldr, flame sensor, water level sensor dan actuator berupa water atomizer, kipas, buzzer serta modul wifi. Untuk data yang berhasil di kirim dari masing-masing sensor sebagai berikut :

\begin{tabular}{|c|c|c|c|c|c|c|}
\hline waktu & suh & kelembaban & Idr & gas & flame & wate \\
\hline $2020-07-02$ 19:24:40 & 26.8 & 81 & 18 & 12.05 & 11 & 2 \\
\hline 2020-07-02 19:24:52 & 27.4 & 76 & 18 & 11.93 & 11 & 2 \\
\hline $2020-07-02$ 19:25:04 & 27.5 & 75 & 18 & 11.75 & 11 & 2 \\
\hline 2020-07-02 19:25:16 & 28 & 75 & 18 & 11.75 & 11 & 2 \\
\hline $2020-07-02$ 19:25:27 & 28.7 & 72 & 18 & 11.75 & 11 & 2 \\
\hline $2020-07-02 \quad 19: 25: 39$ & 29.9 & 68 & 17 & 11.75 & 11 & 2 \\
\hline $2020-07-02$ 19:25:51 & 31.3 & 63 & 17 & 11.46 & 11 & 2 \\
\hline 2020-07-02 19:26:04 & 33.4 & 55 & 17 & 11.46 & 11 & 2 \\
\hline $2020-07-02$ 19:26:16 & 36 & 46 & 18 & 12.73 & 11 & 8 \\
\hline 2020-07-02 19:26:29 & 37.9 & 37 & 18 & 12.24 & 11 & 2 \\
\hline $2020-07-02 \quad 19: 26: 42$ & 37.7 & 42 & 18 & 14.1 & 11 & 7 \\
\hline 2020-07-02 19:26:55 & 36.6 & 47 & 16 & 12.67 & 11 & 2 \\
\hline $2020-07-02 \quad 19: 27: 08$ & 35.2 & 55 & 18 & 14.03 & 11 & 8 \\
\hline $2020-07-02 \quad 19: 27: 20$ & 34 & 57 & 18 & 13.31 & 11 & 2 \\
\hline 2020-07-02 19:27:32 & 33 & 66 & 17 & 13.63 & 11 & 1 \\
\hline $2020-07-02 \quad 19: 27: 44$ & 31.9 & 67 & 1 & 12.67 & 11 & 2 \\
\hline $2020-07-02 \quad 19: 27: 56$ & 31.2 & 67 & 19 & 12.05 & 11 & 2 \\
\hline $2020-07-02$ 19:28:07 & 30.7 & 65 & 18 & 12.05 & 10 & 3 \\
\hline 2020-07-02 19:28:19 & 30.2 & 65 & 18 & 10.99 & 11 & 2 \\
\hline $2020-07-02 \quad 19: 28: 31$ & 29.8 & 66 & 18 & 10.6 & 11 & 2 \\
\hline $2020-07-02$ 19:28:43 & 29.6 & 65 & 18 & 10.32 & 11 & 2 \\
\hline $2020-07-02$ 19:28:54 & 29.4 & 66 & 18 & 10.05 & 11 & 2 \\
\hline 2020-07-02 19:29:06 & 29.2 & 67 & 18 & 9.78 & 11 & 2 \\
\hline $2020-07-02 \quad 19: 29: 18$ & 29 & 68 & 17 & 34.7 & 10 & 3 \\
\hline 2020-07-02 19:29:30 & 28.8 & 67 & 18 & 47.1 & 11 & 2 \\
\hline $2020-07-02$ 19:29:41 & 28.7 & 68 & 18 & 30.42 & 11 & 2 \\
\hline 2020-07-02 19:29:53 & 28.5 & 69 & 16 & 18.78 & 11 & 2 \\
\hline
\end{tabular}

Gambar 5 Data setiap sensor 
Pada gambar 5 merupakan data yang berhasil di kirim ke database terdapat beberapa kolom yaitu waktu, suhu, kelembaban, ldr, gas , flame dan water yang di kirim secara real time dan di tampilkan pada halaman website .

\subsubsection{Hasil Implementasi Software}

Berdasarkan hasil perancangan software sebelumnya yang berupa website diimplementasikan sebagai berikut :

1. Halaman Log in

Halaman login seperti pada Gambar 6 digunakan untuk login ke menu home.

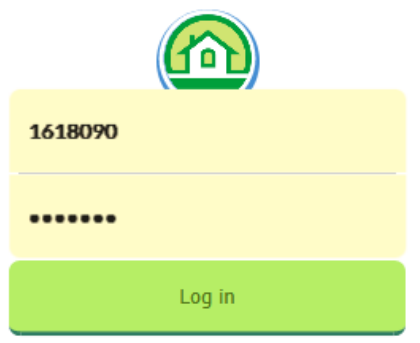

Gambar 6 Tampilan Halaman log in

\section{Halaman Home}

Menu home pada website ini adalah menu tampilan utama disaat pertama kali masuk pada website seperti tampilan Gambar 7



Gambar 7 Tampilan Halaman Home

3. Halaman Suhu

Menu suhu pada website ini adalah menu tampilan suhu pada website seperti tampilan Gambar 8

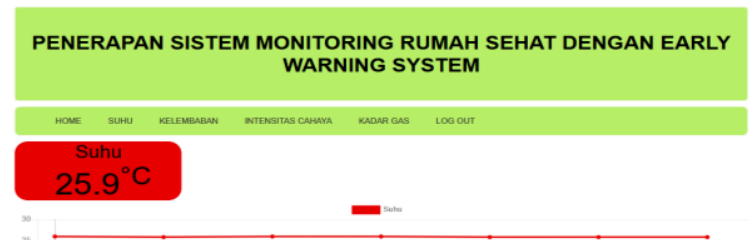

\footnotetext{
Gambar 8 Tamilan Halaman Suhu
}

4. Halaman Kelembaban

Menu suhu pada website ini adalah menu tampilan kelembaban pada website seperti tampilan Gambar 9

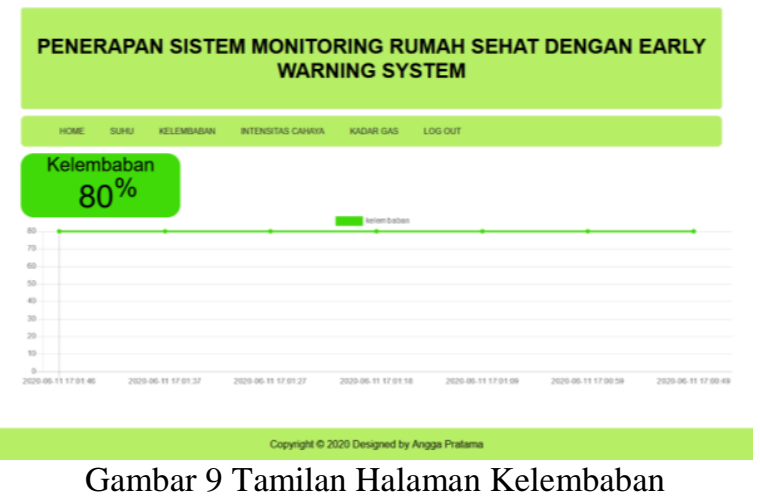

5. Halaman Intensitas Cahaya

Menu suhu pada website ini adalah menu tampilan intensitas cahaya pada website seperti tampilan Gambar 10

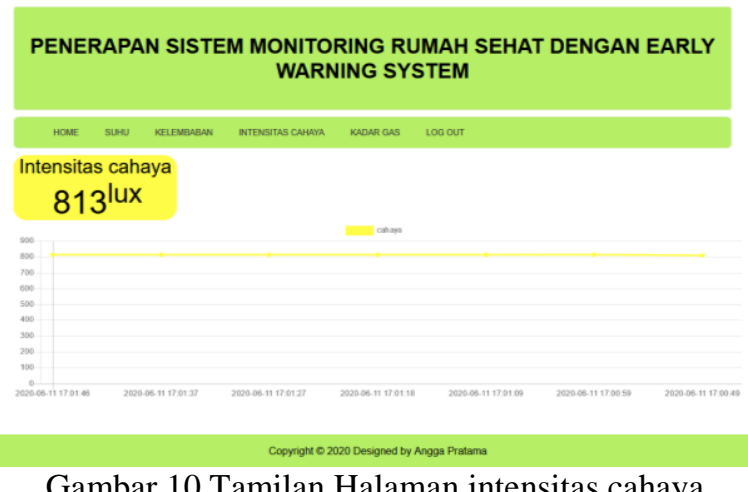

Gambar 10 Tamilan Halaman intensitas cahaya

6. Halaman Kadar Gas

Menu suhu pada website ini adalah menu tampilan kadar gas pada website seperti tampilan Gambar 11

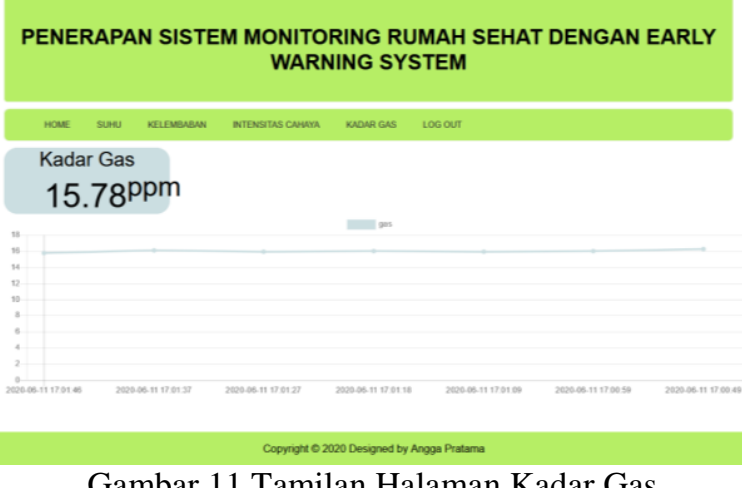

\subsection{Pengujian}

Setelah diimplementasikan penerapan sistem monitoring Helathy smart home dengan early warning system dalam bentuk prototype, akan dilakukan 
pengujian terhadap alat tersebut baik dari segi pengoperasian sensor ataupun komunikasi pengiriman data melalui internet.

\subsubsection{Pengujian Hardware}

Pengujian perangkat keras sendiri adalah kegiatan pembacaan sensor - sensor pada penerapan sistem monitoring Helathy smart home dengan early warning system, mulai dari sensor dht11, sensor mq6 , sensor ldr, flame sensor, water level sensor dan pengujian modul wifi sebagai komunikasi pengiriman data dan penerima data melalui internet.

\section{Pengujian sensor DHT11}

Pengujian deteksi besar suhu dan kelembaban dengan sensor dht11 dilakukan dengan cara membandingkan hasil output sensor pada serial monitor arduino IDE dengan aplikasi thermometer pada ruangan Jika ambang batas untuk suhu dan kelembaban melebihi batas maka water atomizer hidup seperti pada gambar 12

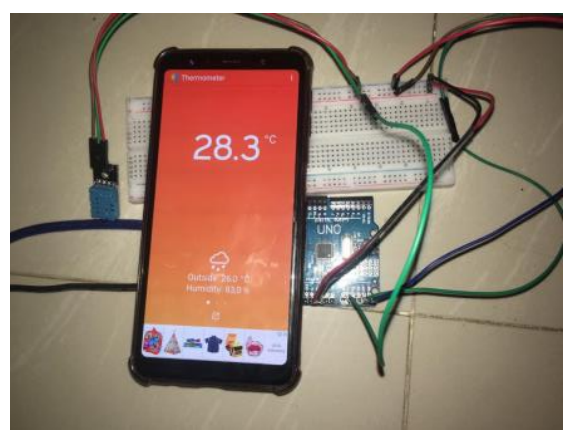

Gambar 12 Pengujian sensor DHT11

Tabel 1 Hasil engujian sensor dht11

\begin{tabular}{|c|c|c|c|c|c|c|c|}
\hline \multirow{2}{*}{$\begin{array}{l}\mathrm{N} \\
\mathrm{o}\end{array}$} & \multicolumn{2}{|c|}{ Nilai sensor } & \multicolumn{2}{|c|}{ Nilai aplikasi } & \multirow{2}{*}{$\begin{array}{c}\text { Water } \\
\text { atomize } \\
\mathrm{r}\end{array}$} & \multirow{2}{*}{$\begin{array}{c}\text { Erro } \\
\mathrm{r} \\
\text { suhu } \\
(\%)\end{array}$} & \multirow{2}{*}{$\begin{array}{c}\text { Error } \\
\text { kelembaba } \\
\mathrm{n}(\%)\end{array}$} \\
\hline & $\begin{array}{c}\text { Suh } \\
\mathrm{u} \\
\left({ }^{\circ} \mathrm{C}\right)\end{array}$ & $\begin{array}{c}\text { Kelembaba } \\
\text { n (\%) }\end{array}$ & $\begin{array}{c}\text { Suh } \\
\mathrm{u} \\
\left({ }^{\circ} \mathrm{C}\right)\end{array}$ & $\begin{array}{c}\text { Kelembaba } \\
\text { n (\%) }\end{array}$ & & & \\
\hline 1 & 29.3 & 67 & 27.8 & 83 & Mati & 5.1 & 23.8 \\
\hline 2 & 29.7 & 52 & 28.6 & 70 & Mati & 3.7 & 34.6 \\
\hline 3 & 30.1 & 47 & 28.9 & 66 & Mati & 3.9 & 40.4 \\
\hline 4 & 31.3 & 39 & 30.4 & 54 & Hidup & 2.8 & 38.4 \\
\hline 5 & 32.1 & 28 & 30.1 & 41 & Hidup & 6.2 & 46.4 \\
\hline \multicolumn{6}{|c|}{ Total Error } & 4.34 & 36.72 \\
\hline
\end{tabular}

Tingkat persentase error dari sensor dht11 tersebut adalah $4,34 \%$ untuk suhu dan $36,72 \%$ untuk kelembaban, hasil perhitungan tersebut didapat dari rata-rata jumlah error pada perbandingan suhu dan kelembaban.

\section{Pengujian sensor Ldr}

Pengujian deteksi besar intensitas cahaya dengan sensor ldr dilakukan dengan cara membandingkan hasil output sensor pada serial monitor arduino IDE dengan aplikasi lux meter pada ruangan seperti pada gambar 13

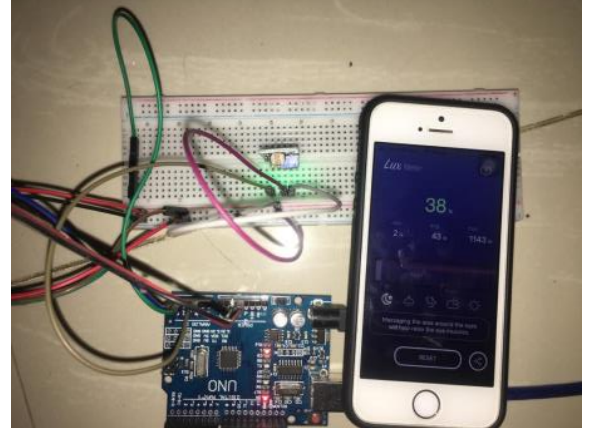

Gambar 13 Pengujian sensor ldr

Tabel 2 Hasil Pengujian sensor ldr

\begin{tabular}{|c|c|c|c|}
\hline No & Nilai ldr & Nilai aplikasi & $\begin{array}{c}\text { Error } \\
(\%)\end{array}$ \\
\hline 1 & 18 & 15 & 16.6 \\
\hline 2 & 29 & 21 & 27.5 \\
\hline 3 & 87 & 79 & 9.1 \\
\hline 4 & 97 & 90 & 7.2 \\
\hline 5 & 120 & 110 & 8.3 \\
\hline \multicolumn{3}{|c|}{ Total Error } & 13.74 \\
\hline
\end{tabular}

Tingkat persentase error dari sensor ldr tersebut adalah $13,74 \%$ hasil perhitungan tersebut didapat dari rata-rata jumlah error pada perbandingan.

\section{Pengujian Flame sensor}

Pengujian flame sensor bertujuan untuk mengetahui kemampuan sensor dalam membaca api pada ruangan. pengujian nya dengan cara memberi api pada flame sensor dan jika terdeteksi api maka buzzer hidup dan mengirim notifikasi seperti pada gambar 14.

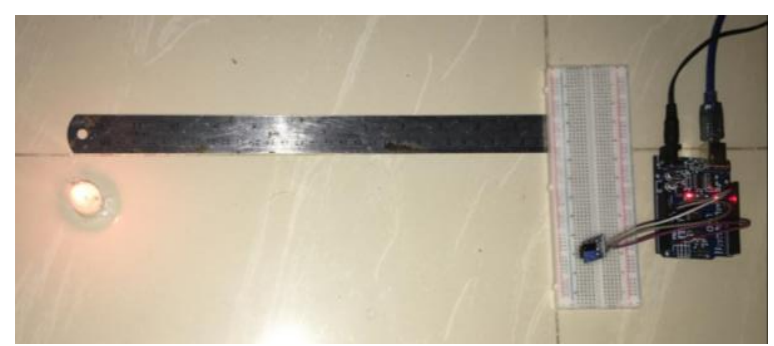

Gambar 14 Pembacaan flame sensor

Tabel 3 Hasil engujian Flame sensor

\begin{tabular}{|c|c|c|c|c|}
\hline No & Jarak (cm) & Indikator & Buzzer & Notifikasi email \\
\hline 1 & 15 & Terdeteksi & Hidup & Ya \\
\hline 2 & 30 & Terdeteksi & Hidup & Ya \\
\hline 3 & 45 & Terdeteksi & Hidup & Ya \\
\hline 4 & 60 & Terdeteksi & Hidup & Ya \\
\hline 5 & 75 & Tidak terdeteksi & Mati & Tidak \\
\hline 6 & 90 & Tidak terdeteksi & Mati & Tidak \\
\hline
\end{tabular}

Sensor ini mampu mendeteksi api dengan menggunakan lilin dengan jarak maksimal $75 \mathrm{~cm}$. 
4. Pengujian water level sensor

Pengujian water level sensor bertujuan untuk mengetahui kemampuan sensor dalam mendeteksi ketinggian air pada ruangan. Pengujian nya dengan cara memberi air pada wadah dan sensor akan menghasilkan nilai di ketinggian tertentu seperti pada gambar 15



Gambar 15 Pengujian water level sensor

Tabel 4 Hasil pengujian water level sensor

\begin{tabular}{|c|c|c|}
\hline No & Kondisi & Nilai sensor \\
\hline 1 & Tidak ada air & $<=100$ \\
\hline 2 & $\begin{array}{c}\text { Ketinggian air } \\
\text { rendah }\end{array}$ & $>100 \&<=260$ \\
\hline 3 & $\begin{array}{c}\text { Ketinggian air } \\
\text { sedang }\end{array}$ & $>260 \&<=325$ \\
\hline 4 & Ketinggian air tinggi & $>325$ \\
\hline
\end{tabular}

Pengujian water level sensor saat tidak ada air nilai sensor $<=100$, ketinggian air rendah nilai sensor $>100 \&<=260$, ketinggian air sedang nilai sensor $>$ $260 \&<=325$ dan ketinggian air tinggi nilai sensor > 325.

\section{Pengujian modul esp 8266}

Pengujian pada modul esp8266 atau disebut juga modul wifi ini diuji dengan cara melakukan pengiriman data pada sebuah suatu web server sebagai output dari hasil baca sensor. Untuk dapat beroperasi, modul wifi dihubungkan pada suatu jaringan internet local yang sama dengan webserver local berada. Alur dari pengujian modul wifi dapat dilihat pada gambar 16

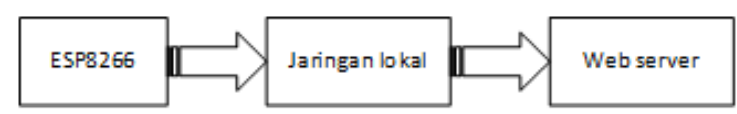

Gambar 16 Digram engujian esp8266
Setelah modul wifi diprogram, modul wifi dapat melakukan pengiriman data ke webserver yang berada pada computer dengan syarat webserver dan modul wifi tersebut ada pada satu jaringan yang sama

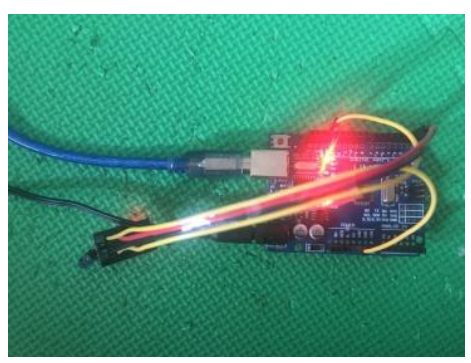

Gambar 17 Pengujian pengiriman data oleh esp8266

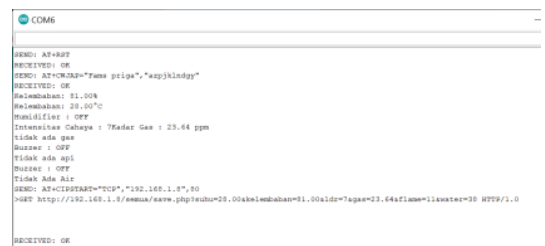

Gambar 18 hasil serial monitor pengujian esp8266

pengujian meliputi dua langkah yakni yang pertama melakukan penghubungan ke jaringan ssid dengan perintah 'SEND : AT+CWJAP='Fams priga' ,'azpjklndgy', jika proses menghubungkan ke jaringan berhasil maka serial monitor akan menampilkan teks "RECEIVED=OK" dan "RECEIV $\mathrm{ED}=$ ERROR" bila gagal. Kemudian pada langkah berikutnya bila proses koneksi berhasil, modul wifi akan melakukan pengiriman data ke web server

\subsubsection{Pengujian Software}

Pengujian software pada penelitian ini dilakukan dengan melakukan pengujian kompabilitas website terhadap web browser. Bertujuan untuk mengetahui apakah halaman website yang dibuat dapat menampilkan keseluruhan data sesuai dengan perancangan tidak hanya satu web browser yang sering digunakan pada umumnya. Hasil uji coba kompabilitas website terhadap web browser seperti ditunjukan pada Tabel 5

Tabel 5 Hasil pengujian software

\begin{tabular}{|c|c|c|c|c|}
\hline \multirow{2}{*}{ No } & \multirow{2}{*}{ Aspek pengujian } & $\begin{array}{c}\text { Mozila } \\
\text { firefox } \\
(77.01 .)\end{array}$ & $\begin{array}{c}\text { Microsoft edge } \\
(44.18362 .449 .0)\end{array}$ & $\begin{array}{c}\text { Google chrome } \\
(83.0 .4103 .97)\end{array}$ \\
\hline 1 & Halaman login & $\checkmark$ & $\checkmark$ & $\checkmark$ \\
\hline 2 & Halaman home & $\checkmark$ & $\checkmark$ & $\checkmark$ \\
\hline 3 & Halaman suhu & $\checkmark$ & $\checkmark$ & $\checkmark$ \\
\hline 4 & $\begin{array}{c}\text { Halaman } \\
\text { kelembaban }\end{array}$ & $\checkmark$ & $\checkmark$ & $\checkmark$ \\
\hline 5 & Halaman intensitas & $\checkmark$ & $\checkmark$ & $\checkmark$ \\
\hline 6 & cahaya & & & $\checkmark$ \\
\hline 7 & Halaman kadar gas & $\checkmark$ & $\checkmark$ & $\checkmark$ \\
\hline 8 & Cetak record & $\checkmark$ & $\checkmark$ & $\checkmark$ \\
\hline 9 & Notifikasi & $\checkmark$ & $\checkmark$ & $\checkmark$ \\
\hline
\end{tabular}




\section{KESIMPULAN DAN SARAN}

\subsection{Kesimpulan}

Dengan adanya penerapan sistem monitoring

Helathy smart home dengan early warning system berbasis website yang telah di buat, maka dapat diambil kesimpulan yaitu :

1. Sistem yang dibuat dapat memonitoring suhu, kelembaban, intensitas cahaya, kadar gas, deteksi api, deteksi ketinggian air pada Helathy smart home melalui website.

2. Dari hasil pengujian sensor dht11 dengan aplikasi thermometer yang telah diuji sebanyak 5x (lima kali) tingkat persentase error dari sensor tersebut sebesar $4,34 \%$ untuk suhu dan $36,72 \%$ untuk kelembaban.

3. Dari hasil pengujian sensor ldr dengan aplikasi lux meter yang telah di uji sebanyak 5x (lima kali) tingkat persentase error dari sensor tersebut sebesar $13,74 \%$.

4. Dari hasil pengujian flame sensor yang telah diuji sebanyak 6x (enam kali) bahwa sensor ini mampu mendeteksi api dengan mengguanakan lilin dengan jarak maksimal $75 \mathrm{~cm}$.

5. Dari hasil pengujian water level sensor saat tidak ada air nilai sensor $<=100$, ketinggian air rendah nilai sensor $>100 \&<=260$, ketinggian air sedang nilai sensor $>260 \&<=325$, ketinggian air tinggi nilai sensor $>325$.

6. Website dapat berjalan dengan baik pada browser Mozilla firefox (77.01), Microsoft edge (44.18362.449.0), dan google chrome (83.0.4103 .97).

\subsection{Saran}

Adapun beberapa saran yang dapat diberikan setelah melakukan beberapa pengujian sistem, diantaranya :
1. Delay yang terlalu lama pada modul esp8266 saat menghubungkan ke jaringan wifi dan saat pengiriman data, maka modul tersebut dapat di ganti dengan modul wifi yang lain.

2. Dapat diberikan beberapa tambahan output lagi pada alat tersebut agar monitoring berfungsi lebih maksimal, seperti penambahan pompa air

\section{DAFTAR PUSTAKA}

[1] Joseph Dedy Irawan, Sonny Prasetio, Suryo Adi Wibowo. 2015. Early warning system for building automation system:stimata.ac.id

[2] Akh. Farid. 2017. Sistem Monitoring Dan Kontroling Pada Smart Building Dengan Penerapan Iot (Internet Of Things). Malang:ITNJurnal

[3] Saifullana. 2018. sistem pendeteksi kebakaran rumahterintegrasi smartphone dan aplikasi online.

[4] Wahyu indianto. 2017. perancangan sistem prototipe pendeteksi banjir peringatan dini menggunakan arduino dan php.

[5] Widyanto. 2014. Alat Deteksi Kebocoran Tabung Gas elpiji Berbasis Mikrokontroler

[6] Zulhipni. 2017. Perancangan Monitoring Suhu Ruangan Menggunakan Arduino Berbasis Android

[7] Sigit Wasista, Setia Wardhana dkk. 2019. Aplikasi Internet of Things dengan Arduino dan Android. Yogyakarta: CV Budi Utama

[8] Nermin Ozgulbaz. 2011. Suirveillance Technologies and Early Warning System : Data Mining Aplications For Risk Detection.IGI Global :United States

[9] Abdul Kadir. 2013. Panduan Praktis Mempelajari Aplikasi Mikrokontroler dan Pemrogramannya Menggunakan Arduino. Yogyakarta: Penerbit ANDI. 